\title{
Ethnocentrism: Enemy of Productive and Happy Multicultural Workplace
}

\author{
Aneesya Panicker ${ }^{1}$, Avnish Sharma ${ }^{2}$ \\ ${ }^{1}$ Associate Professor, Institute of Business Management, GLA University, Mathura, U.P., India. \\ E-mail: aneesya.panicker@gla.ac.in, panickeraneesya@gmail.com \\ ${ }^{2}$ Assistant Professor, Institute of Business Management, GLA University, Mathura, U.P., India. \\ E-mail: avnish.sharma@gla.ac.in; avnish.gla@gmail.com
}

Article History: Received: 11 January 2021; Accepted: 27 February 2021; Published online: 5 April 2021

\begin{abstract}
Organizations and professionals are usually unaware about the fundamental rationale behind workplace ethnocentrism. Due to globalization today's workplace are becoming multi-cultural, thus to address and understand the intricacies of ethnocentrism and being sensitive towards the issue is the need of the hour. Effective management of culturally diversified workplace is significant point of concern. As it may germinate challenges before the organization, one such challenge is related with ethnocentric feeling among culturally diversified workforce towards each other. This paper will explain the concept of ethnocentrism at workplace, the psychology of ethnocentric tendency and the various problems that an ethnocentric view presents before the multicultural organization while dealing with culturally diversified employees by synthesizing various research studies done in this area, comprising of examining various approaches to ethnocentric tendency. It also answers why diversity at workforce that exemplifies a changing world and contemporary workplace which is vital for creating competitive work environment that enhance work productivity. It will also discuss the implication of ethnocentrism in multicultural organizations and how to avoid the intricacies of ethnocentric phenomenon and resultant conflicts and disruptions arising at the workplace.
\end{abstract}

Keywords: Ethnocentrism, Diversity, Ethnocentric Tendency, Workplace Behavior.

\section{Introduction}

Diversity is an inevitable fact of today's workplace. Managing multicultural is undeniably a challenge before the managers. Organizations are experiencing diversity among their workforce and formulating strategies to derive best out of this. Cultural diversity spring from varied sources, the most significant one are revolution brought by advancement in information and communication technology (ICT) and increased immigration both at national and international level. Concept of multiculturalism with respect to India is not novel. India is one of the diverse nations in the world due to diversity in languages, ethnicity, religion, cultures and communities.

The enemy of contented multicultural workplace is the negative attitude of individuals towards other's culture and considering own culture as right and logical. One of the specialists in the field of conflict is the Aviary Group, they opine that tendency of ethnocentrism often results into intra-group conflict leading to exclusion, partiality and hostile behavior in the organization. If the conflicts are not timely controlled this may result into poor performance and productivity. To address the issue of ethnocentrism and resultant workplace conflicts, managers and employees should decisively analyze their significant cultural biases and train themselves about the minutiae of others cultures through open channels of communication.

"Ethnocentrism" is a Greek word which means "nation" and "center." This feeling germinates as a result of limited exposure and information about other cultures leading to the feeling of superiority about one's own culture. In other words, it refers to "the way an individual think that their own group is superior to others". Ethnocentrism basically refers to judging other groups from their own cultural point of view. Every one of us think that we are open minded, but the fact is, we all are ethnocentric, and it is very difficult to avoid it.

Sumner (1906), originated the term ethnocentrism and viewed it as an individual's view of perceiving their group as the center of all, and ranking others accordingly. He opines that each group nurtures its specific vanity and conceit, claims itself grander, elevates its own mysticisms and looks with disapproval on strangers.

In fact, ethnocentrism is a form of racism. The conviction that one's own race is superior to that of others is the result of certain customs, practices or lifestyles. In a diverse workplace, ethnocentric thoughts create tension. Tension results into tarnished teamwork, decline in productivity, absenteeism and employee turnover. Eventually resulting into increased costs and lost profits ultimately affecting the bottom line of the organization. Thus, human resource managers are supposed to be proactive towards managing ethnocentrism. The first step to dealing with ethnocentrism is understanding, what it is and where it comes from? Ethnocentric people may make sweeping judgments about people, based on which they make decisions about jobs or friendships.

\section{Background}

As Sumner (1906) connects the concept of ethnocentrism as the way individuals judge themselves superior to other groups, in other words they see the world through the lens of their own cultural values and standards. This eventually alter their view of outer world, often resulting into false conception about others' cultural norms and 
assumptions. Which in turn interrupt or impede business venture. For instance, ethnocentrism can impede coherent strategic planning as it alters pivotal aspects of strategic thinking (Booth, 1979). Ethnocentric tendencies tend to create intra and inter group conflicts when managers give more importance to the management ideologies and systems while ignoring other country's values, customs, norms and traditions (Begley \& Boyd, 2003). It has been observed that when organizations become international and they implement a corporate identity strategy that is having an ethnocentric view tend to backfire (Thomas and Hill, 1999). Inopportunely, the issue of ethnocentrism will be enduring around the world (Ogretir \& Ozcelik, 2008; Bizumic, Duckitt, Popadic, Dru, \& Krauss, 2009). Almost every professional or practitioner tend to exhibit ethnocentric behavior at their workplace in their professional life. Though the concepts related to ethnocentrism like gender and cultural diversity, ethics in business and individual differences, etc are usually deliberated at workplace, the issue of "ethnocentrism" is not archetypally recognized as a strategic concern for discussion at workplace. Thus, the initial onus lies on the education system of any nation to prepare their people for the world around them (Nehrt, 1993). Therefore, the professionals must realize and understand the impact of ethnocentrism on their career success or organization success. Many researchers believe that ethnocentric behavior is one of the element basic human nature (Lynn, 1976; Mihalyi, 1984; Rushton, 1989). Many people despite of being biased towards their own cultures, yet usually they are not aware of their own cultural inclinations (Cunningham, Nezlek, \& Banaji, 2004; Barger, 2008). In this line the present paper also provides a brief overview on the ethnocentric psychology for better understanding.

\section{Psychology Behind Ethnocentric Tendencies}

Numerous research theory has been established in an effort to elucidate the roots of ethnocentrism. Major ethnocentric theories are summarized below for better understanding the underpinning od this concept. First thing that comes in mind is, what is the reason behind individual's ethnocentric view point? One hypothesis is individuals are taught about ethnocentric tendencies from the very beginning as religious or political attitudes are taught by the parents (Mosher \& Scodel, 1960). A second hypothesis is related with the nurturing practices of ascetic parents.

The Authoritarian Personality Theory: According to this theory the children of authoritative parents tend to be least expressive about resentment towards their parents. Alternatively, they use to project their power on weaker people. Therefore, people with authoritative personalities classify people into "we" and "they" and assessing one's own group as the outstanding one (Adorno, Frenkel-Brunswik, Levinson, \& Sanford, 1950).

The Belief Congruence Theory proposes that the prime factor of ethnocentric tendency of an individual is the congruence between the two individual's value system, cultural and religious attitudes and beliefs (Rokeach \& Rothman, 1965).

The Similarity-Attraction Theory propounds that we are tend to be attracted towards those individuals who are similar to us because these individuals authenticate our self-beliefs. In case of high similarity, mutual attraction is assumed to happen. Otherwise, dissimilarity inspires a hostile orientation towards other party (Bryne, 1971).

The Realistic Conflict Theory advocates that resentment among two individuals or groups occurs because of real or perceived contradictory objectives that germinates competition among them. Feelings of offence ascend because each group wishes to win at the cost if other expense, which results into destructive stereotypes and hostility towards other group members (Sherif, Harvey, White, Hood, \& Sherif, 1961).

The Frustration-Aggression Theory (Berkowitz, 1972; Dollard, Doob, Miller, Mowrer, \& Sears, 1939) advocates that individuals tends to show resentment when they feel or believe that the way they are being treated by others is not fair, which results into inter group conflict even intra group conflict which eventually intensify into ethnocentrism (Grant \& Brown, 1995).

Another interesting theory is the Scapegoat Theory, which opines that individuals may be prejudice towards a specific group and use that group as a target to vent their anger because of frustration on any other issues. For instance, the Scapegoat Theory proposes that the Jewish people are treated as scapegoats by Germans for their national issues. This accumulation of anger towards Jewish people resulted in massive hatred among the German population.

The Social Identity Theory proposes that individuals tend to associate with those groups that identify with their self-esteem. Nevertheless, group membership is not sufficient for conformity of self-esteem. Instead, they need to understand that it is important to be part of "right" group, that mark effective distinction between the ingroup and the out-group. Constructive comparisons between groups make people feel superior about their group membership (Tajfel \& Turner, 1985).

The Relative Deprivation Theory (Stouffer, Suchman, DeVinney, Star, \& Williams, 1949) states that the dissatisfaction individuals perceive when they relate their situations with similar individuals and understand that others have more than what they have. It is a state that is examined by making comparison with others who are in advantageous situation. In addition to this ethnocentrism is also about making deceitful assumptions about other's way of thinking on the basis of one's limited experience about others culture (Barger, 2008). In other 
words, individuals without any thought perceive about other groups on the basis of their own frame of reference, perceiving the other group as abnormal. As a result, individuals unintentionally disdain and confirm their belief as superior to others, as they do not understand others. Therefore, behaviors associated with ethnocentrism frequently comprises of tainted relationship with others. In addition to this, ethnocentric behaviors may involve preferential and biased treatment within groups like reliance, collaboration and fairness criteria which is termed as in-group biasness (LeVine \& Campbell, 1972; Brewer, 1979; Platow, McClintock, \& Liebrand, 1990; Mullen, Brown, \& Smith, 1992; Wit \& Kerr, 2002; Yuki, Maddux, Brewer, \& Takemura, 2005). Furthermore, research findings reflect that when group identity is visible favoritism within-group is inevitable (Otten \& Moskowitz, 2000; Otten \& Wentura, 1999). Certainly, ethnocentrism is a "common phenomenon that is deeply rooted in almost all areas of inter-group relations" (Lewis, 1976). The feeling of superiority about one's own culture can adversely affect the way individuals relate with others at workplace (Schermerhorn, Jr., 2010). Besides, the international business attitude of organizations is one of eminent factor that significantly impact the success of their business at international level. Subsequently, incisive organizations realize the importance of decreasing and eradicating the ill effects of ethnocentrism by enhancing the level of awareness of employees about todays' competitive business scenario and advancing industry relationships (Grant \& Wren, 1993).

\section{Implications of Ethnocentrism in Multicultural Organizations}

Tendency of ethnocentric behavior usually occurs in culturally diversified nations and India is one such nation which is culturally diversified. Ethnocentrism germinates misunderstanding among diversified employees because of difference in perception, upbringing, varied rituals and customs etc. Outcome of such misunderstanding may result in lack of trust and cooperation leading to high turnover, absenteeism and lawsuits resulting into financial cost (Daft 1997; Robinson and Dechant 1997).

Feeling of prejudice and non-acceptance among the employees hamper the work productivity not only at individual level but at organizational level also which is the result of ineffective communication system (Loden and Rosener 1991; Daft 1997). All this turmoil tarnishes the corporate image, which means if an organization is known for alienating diversified employees, they will face difficulty in attracting qualified applicants at the time of limited supply of labor (Daft 1997; Elmuti 2001).

On one hand people from minority group feel oppressed and dejected by people of powerful groups through prejudice and discrimination leading to feeling of inferiority. On the other hand, ethnocentrism also leads to feeling of pride among members of majority group because of high sense of identity and self-esteem.

Organizations that capitalize on the potentialities of diversified workforce will have edge over those organizations that do not confront the challenge created by ethnocentrism (Kandola and Fullerton 1994; Karpin 1995). Employees from diversified background when perceive their organization as an inclusive one, this will lead to high sense of employee commitment and outcome (Loden and Rosener 1991; Daft 1997).

\section{Practical Implications of Ethnocentrism on Human Resource Managers}

Ethnocentrism put forth many challenges before the human resource managers. Studies have revealed that there is significant negative correlation between ethnocentrism and individual's perceptions of knowledge, skills, abilities, character, social attraction, and hiring decisions (James W. Neuliep, Stephanie M. Hintz \& James C. McCroskey (2007). When employees develop a superiority complex about their culture with respect to others culture the role of human resource managers expects them to create diversify inclusive workplace through mandatory diversity oriented recruitment and selection policies, diversity awareness training programs and varied team-building exercises. State and central laws have enforced many laws to prevent discrimination of employees with respect to their gender, caste and category in the form of affirmative action and equal employment opportunity acts. Thus, human resource managers are expected to be proactive towards such challenges from the beginning.

Fights, arguments and violence have been associated with ethnocentrism in the work place. Employee trust is compromised beyond repair. Human resource managers perform counseling and damage control for the workplace. These distractions result in lost profits and productivity. Legal actions are taken against employees and companies engaging in ethnocentric practices. Proper training and enforcement are vital to protecting corporate interests and employees.

\section{Ways to Overcome Ethnocentrism}

We live in a smaller world today than ever before. Our world is connected with innovative technologies like internet, supersonic jets and high-speed channels of communication. More we open up to this world; we experience different customs and cultures more regularly. To make a place for our cultural values we tend to create a shield in which we develop a feeling of being superior to others culture and start making prejudicial judgments about members of other group. This tendency is known as ethnocentrism. Dealing with this involves tolerance, balanced understanding and accepting that we don't understand others culture and thus making false assumptions about them. To avoid this, we must start observing the reactions of others this will help us to better 
control our prejudices and have more effective and sensible understanding about others. Further, a soft skill training on cultural stereotype and ethnocentrism will definitely minimize its negative effect on people performance at work (Tripathy, 2019).

\section{Discussion and Conclusion}

Due to globalization today's workplace are becoming multi-cultural, thus to address and understand the intricacies of ethnocentrism and being sensitive towards the issue is the need of the hour. Still business organizations and professionals are not familiar with the fundamental reasoning behind ethnocentrism and its probable consequences at workplace. Present study offers a way to facilitate business organizations and professionals to recognize the significance of ethnocentric tendencies, thereby bringing sensitivity about intercultural issues and diverse characteristics of employees. It is noteworthy to pen down some of the suggestions proposed through the paper. First, ethnocentrism is a subtle concept to understand and discuss. Thus, organizations should try to disseminate knowledge about this issue through experienced trainers. Second, additional training programs should be designed for employees who are regularly interacting with individuals from other country or cultures by means of various emersion courses, sensitivity training, visits to the locale, etc. Ethnocentrism is one of the small constituent of diversity. Emphasizing ethnocentrism along with focus on various diversity dimensions, will not inculcate and strengthen the worth of appreciating diversity in complete sense.

Further, today's manager cannot ignore diversity at workplace. They pose many challenges before them one such challenge is related with ethnocentrism. This tendency leads to many financial and non-financial losses to the organization, like- absenteeism, employee turnover, decrease in individual and organizational productivity, reduced commitment, stained corporate image. Thus, organizations can have competitive advantage over others if they effectively manage diversity at workplace.

One has to remember that every individual has some unique traits and we can ever have complete understanding of others culture, until and unless we are empathetic towards them. It is not just about managing various cultural groups, but also respecting the expectations of diverse employees (Jenner 1994; Kandola et al. 1995). Organizations that treat their people as key to organizational success tend to manage cultural diversity by brining flexibility and transparency in organizational structure, policies and practices, commitment towards diversity, employee empowerment, diversity awareness training-cum-mentoring programs.

\section{References}

3. Adorno, T.W., Frenkel-Brunswik, E., Levinson, D.J., \& Sanford, R.N. (1950). The authoritarian personality. New York: Harper \& Row.

4. Barger, K. (2004). Ethnocentrism. What is it? Why are people ethnocentric? What is the problem? What can we do about it?. Indiana University, Department of Anthropology.

5. Begley, T.M., \& Boyd, D.P. (2003). Why don't they like us Overseas? Organizing U.S. business practices to management culture clash. Organizational Dynamics, 32, 357- 371.

6. Berkowitz, L. (1972). Frustration, comparisons, and other sources of emotional arousal as contributors to social unrest. Journal of Social Issues, 28, 77-91.

7. Brewer, M.B. (1979). In-group bias in the minimal inter-group situation: A cognitive-emotional analysis. Psychological Bulletin, 86, 307-324.

8. Bizumic, B., Duckitt, J., Popadic, D., Dru, V., \& Krauss, S. (2009), “A cross-cultural investigation into a reconceptualization of ethnocentrism”, European Journal of Social Psychology, 39, 871-899.

9. Booth, K. (1979). Strategy and ethnocentrism. London: Croom Helm Ltd.

10. Byrne, D. (1971). The attraction paradigm. New York: Academic Press.

11. Cox, T.H., \& Blake, S. (1991). Managing Cultural Diversity: Implications for Organizational Competitiveness. Academy of Management Executive, 5(3), 45-56.

12. Cunningham, W.A., Nezlek, J.B., \& Banaji, M.R. (2004). Implicit and explicit ethnocentrism: Revisiting the ideologies of prejudice. The Society for Personality and Social Psychology, Inc., 30, 1332-1346.

13. Daft, R.L. (19970). Management 4th edition. Harcourt Brace College Publisher, USA.

14. Elmuti, D. (2001). Preliminary analysis of the relationship between cultural diversity and technology in corporate America. Equal Opportunities International, 20(8), 1-16.

15. Grant, E.S., \& Wren, B.M. (1993). Student ethnocentrism: Its relevance to the globalization of marketing education. Marketing Education Review, 3, 10-17.

16. James, W.N., Stephanie, M.H., \& James, C.M. (2007). The influence of ethnocentrism in organizational contexts: perceptions of interviewee and managerial attractiveness, credibility, and effectiveness. Journal of Communication Quarterly. 
17. Kandola, R. (1995). Managing Diversity: Succeeding Where Equal Opportunities Has Failed. Equal Opportunities Review, 59, 31-36.

18. Karpin, D.S. (1995). Enterprising Nation: Renewing Australia's Managers to Meet the Challenge of the Asia-Pacific Century. The Australian Government Publishing Service, Canberra.

19. Lewis, I.M. (1976). Social anthropology in perspective. United Kingdom: Penguin.

20. LeVine, R.A., \& Campbell, D.T. (1972). Ethnocentrism. New York: John Wiley \& Sons.

21. Loden, M., \& Rosener, J.B. (1991). Workforce America: Managing Employee Diversity as a Vital Resource. Business One Irwin, USA.

22. Lynn, R. (1976). The sociobiology of nationalism. New Society.

23. Mihalyi, L.J. (1984). Ethnocentrism vs. nationalism: Origin and fundamental aspects of a major problem for the future. Homboldt Journal of Social Relations, 12, 95-113.

24. Mosher, D.L., \& Scodel, A. (1960). Relationships between ethnocentrism in children and the ethnocentrism and authoritarian rearing practices of their mothers. Child Development, 31, 369-376.

25. Nehrt, L.C. (1993). Business school curriculum and faculty: Historical perspectives and future imperatives. In S. Tamer Cavusgil (Ed.), Internationalizing business education: Meeting the challenge. Michigan: Michigan State University Press.

26. Ogretir, A.D., \& Ozcelik, S. (2008). The study of ethnocentrism, stereotype and prejudice: Psychoanalytical and psycho-dynamic theories. Journal of Qafqaz University, 236-244.

27. Otten, S., \& Moskowitz, G.B. (2000). Evidence for implicit evaluative in-group bias: Affect-biased spontaneous trait inference in a minimal group paradigm. Journal of Experimental Social Psychology, $36,77-79$.

28. Otten, S., \& Wentura, D. (1999). About the impact of automaticity in the minimal group paradigm: Evidence from affective priming tasks. European Journal of Social Psychology, 29, 1049-1071.

29. Platow, M.J., McClintock, C.G., \& Liebrand, W.G. (1990). Predicting intergroup fairness and in-group bias in the minimal group paradigm. European Journal of Social Psychology, 20, 221-239.

30. Robinson, G., \& Dechant, K. (1997). Building a Business Case for Diversity. Academy of Management Executive, 11(3), 21-31.

31. Rokeach, M., \& Rothman G. (1965). The principle of belief congruence and the congruity principle as models of cognitive interaction. Psychological Review, 72, 128-142.

32. Rushton, J.P. (1989). Genetic similarity, human altruism, and group selection. Behavioral and Brain Sciences, 12, 503-559.

33. Schermerhorn, J.R., Jr. (2010). Management (10th ed.). Hoboken: John Wiley \& Sons, Inc.

34. Sherif, M., Harvey, D.J., White, B.J., Hood, W.R., \& Sherif, C.W. (1961). Intergroup conflict and cooperation: The robbers' cave experiment. Oklahoma: Institute of Group Relations.

35. Stouffer, S.A., Suchman, E.A., De Vinney, L.C., Star, S.A., \& Williams, R.M., Jr. (1949). The American soldier: Adjustment during army life. Princeton: Princeton University Press, 1 .

36. Sumner, W.G. (1906). Folkways: The sociological importance of usages, manners, customers, mores, and morals. New York: Giann and Company.

37. Tajfel, H., \& Turner, J.C. (1985). The social identity theory of intergroup behavior. In S. Worchel \& W. Austin (Eds.), Psychology of intergroup relations. Illinois: Nelson-Hall.

38. Thomas, M., \& Hill, H. (1999). The impact of ethnocentrism on devising and implementing a corporate identity strategy for new international markets. International Marketing Review, 16, 376-390.

39. Thomas, R. (1991). Beyond race and gender: Unleashing the power of your total workforce by managing diversity. AMACOM, USA.

40. Tripathy, M. (2019). Subduing Cultural Stereotype \& Ethnocentrism In Business Organizations: A Soft Skills Stance. Journal of Social Humanities, 12, 28.

41. Wit, A.P., \& Kerr, N.L. (2002). Me versus just us versus us all: Categorization and cooperation in nested social dilemmas. Journal of Personality and Social Psychology, 83, 616-637.

42. Yuki, M., Maddux, W.W., Brewer, M.B., \& Takemura, K. (2005). Cross-cultural differences in relationships - and group-based trust. Personality and Social Psychology Bulletin, 31, 48-62.

43. https://www.hrexchangenetwork.com/hr-talent-management/articles/curb-your-ethnocentrism 